\title{
How to Increase Learning Motivation Using Hypnotherapy
}

\author{
Oki Dermawan, Busmayaril, Defriyanto, Fachrur Rozi
}

UIN Raden Intan Lampung, Indonesia

okidermawan@radenintan.ac.id

Submitted : 18-09-2020, Revised : 05-05-2021, Accepted : 31-05-2021

\begin{abstract}
Each individual must have different motivation to learn, some are low, and some are high. Students' motivation to learn can be expressed from outside or within the individual. The result of low learning motivation is not being excited during the learning process. Low learning motivation can work for anyone. This problem occurs in 29 State Junior High School, Bandar Lampung students experience low learning motivation with characteristics such as chatting, sleeping, not paying attention while in the learning process. So it is necessary to increase the motivation to learn by using hypnotherapy. This study aims to reveal the effect of hypnotherapy on learning motivation, followed by students. This research is quantitative with a Quasi-Experimental research type, and One group pretest-posttest design research design. The results show the difference between before and after being given hypnotherapy. So it can be denied that hypnotherapy affects learning motivation in students. Hypnotherapy can arouse students' enthusiasm in learning and can suggest various positive things that aim to increase self-confidence, motivation, and a positive self-image.
\end{abstract}

Keywords: Hypnotherapy; Junior High School; Learning Motivation

\section{Introduction}

Motivation has a significant role and influence on the learning process and outcomes. Without motivation, the learning process does not go well, learning objectives are not achieved, and student learning outcomes are less than optimal and even disappointing. Motivation is a change in energy in a person's personality characterized by the emergence of reactions and affective to achieve goals (Ryan et al., 2019). Furthermore, motives are also a set that can make individuals carry out certain activities to achieve goals (Locke \& Schattke, 2019). Thus motivation is an impetus that can lead to certain behaviours directed to achieve a certain goal. The behaviour or actions shown by a person to achieve certain goals depend on the motives he has. As stated by research which says that the strengths, weaknesses or enthusiasm of the efforts a person makes to achieve goals will be determined by the strengths and weaknesses of the person's motives (Denzinger \& Brandstätter, 2018).

The existence of good motivation in learning will show good results too. Someone who learns will be able to produce good achievements. The intensity of a student's motivation will greatly determine the level of achievement of his learning achievement (Becirovic, 2017). Motivation is a psychological symptom related to objects or activities that stimulate individual feelings and contribute to the success of the learning process. Students who have learning motivation will try to complete their assignments, do not give up quickly, have a high interest in learning, are happy with challenging assignments, and believe that something is right then try to defend their opinion (Lin \& Chen, 2017). Thus students who have high learning motivation will be able to achieve good learning achievements.

However, in reality at 29 State Junior High School, Bandar Lampung, some students seem to have low learning motivation. 29 State Junior High School, Bandar Lampung is an excellent junior high school in Bandar Lampung, although some students lack high learning motivation and are interested in the material presented. Some students play around and don't 
pay attention when the teacher explains the material, some students seem less enthusiastic about the learning process, and some are embarrassed to ask the teacher.

Researchers also conducted interviews with Guidance and Counseling teachers at 29 State Junior High School, Bandar Lampung. There are several eighth-grade students of 29 State Junior High School, Bandar Lampung who have low learning motivation. This is evidenced by the reports of several subject teachers. The subject teacher stated that the student when he was in class did not look excited when he was in class. Learning, not paying attention, chatting with classmates and even falling asleep during the learning process, the guidance and counselling teacher also states that guidance and counselling services have not been implemented specifically to overcome the low learning motivation experienced by students. Therefore, guidance and counselling teachers recommend conducting research that focuses on research on students who are indicated to have low learning motivation according to predetermined indicators.

Based on the preliminary study, it can be understood that the factors that cause students to have low learning motivation are that they are lazy to learn from the start and are added because of the less preferred subjects and teachers. The strategy chosen by the researcher is hypnotherapy. Hypnotherapy is an application for therapeutic purposes, which can overcome learning stress, increase motivation, can improve a person's bad habits and can also strengthen memory. With the hypnotherapy method, students will be helped so that it will expedite the learning process. Hypnotherapy can arouse students' enthusiasm for learning and can suggest various positive things that aim to increase self-confidence, motivation, and a positive self-image (Alizamar et al., 2018). Hypnotherapy is defined as a state of mind where the logical analytical function of the mind is reduced so that it allows the individual to enter a subconscious or unconscious, where various internal potentials are stored that can be utilized to further improve the quality of life. The individual who is in a "hypnotic trance" is more open to suggestions and can be neutralized from fear (phobia), trauma or pain. Individuals who experience hypnosis can still be aware of what is happening around them along with various stimuli provided by the therapist (Taufik \& Upoyo, 2019). The use of suggestions in hypnotherapy, either directly or indirectly, to create better suggestibility conditions where there are shortcuts to the critical abilities of the mind, as well as creating selective attention to the suggestions given (Khayatjadidi et al., 2021).

With the use of hypnotherapy on students who have low learning motivation, it is expected that learning motivation will increase. This statement is supported by research that found the effect of hypnotherapy on learning motivation of elementary school students, Semarang. There is a significant difference in the change or increase in learning motivation between the group receiving hypnotherapy therapy and the group not receiving hypnotherapy therapy(Imelda et al., 2019). Furthermore, another study tested Hypnoteaching on Student Motivation. There is an effect of Hypnoteaching with Learning Motivation which can be seen based on the value of $t$ count $=1.831$ which is greater than t table 1.669 at an error level of $5 \%$. In other words, there is a difference between Learning Motivation without Hypnoteaching and Learning Motivation with Hypnoteaching, meaning that the more Hypnoteaching is applied, the Student's Learning Motivation will increase(Puspitasari, 2018). From the above background, the authors are interested in researching and examining more deeply the effect of hypnotherapy on increasing learning motivation. The problem that arises 
in this research is whether hypnotherapy affects the learning motivation of students of 29 State Junior High School Bandar Lampung.

\section{Methods}

This research design uses quasi-experimental or quasi-experimental. The quasiexperimental design in this study is a One group pretest-posttest design, namely a research design that contains a pre-test before being given treatment and a post-test after being given treatment. The total population consisted of 27 students so that the sample in this study was 5 students who were part of the characteristics of the population. Sampling in this study using the purposive sampling technique. The sample in this study were students who indicated having low learning motivation. The instrument used is an instrument of learning motivation. In this study, only three aspects were taken because these three aspects were more dominant in each person. These three aspects are:

a. Prefer to work independently

b. Do not get bored quickly with tasks

c. Enjoy finding and solving problems.

Analysis of $\mathrm{z}$ test data or repaired sample $\mathrm{z}$ test. Analysis of this data using the help of the SPSS 20 program.

\section{Results and Discussion}

Based on the data obtained, the authors determined hypnotherapy services for 5 students who were taken by purposive sampling technique to be sampled. The author furthermore agrees to do hypnotherapy on the day, date and time that has been determined. Implementation schedule that the author carried out at 29 State junior High School, Bandar Lampung. Can be seen in table 1 .

Table 1. of Research Implementation Schedule

\begin{tabular}{|c|c|c|c|}
\hline No & Day / Date & Time & Activity \\
\hline 1 & $\begin{array}{c}\text { Tuesday, } \\
22 \text { October } 2019\end{array}$ & $\begin{array}{l}\text { 09:00 } \\
\text { WIB }\end{array}$ & $\begin{array}{l}\text { Met Up with BK teachers and } \\
\text { Vice headmaster of Curriculum } \\
\text { to ask permission to carry out } \\
\text { research and discuss the } \\
\text { schedule for implementing } \\
\text { group counseling services }\end{array}$ \\
\hline 2 & $\begin{array}{l}\text { Wetnesday, } \\
23 \text { October } 2019\end{array}$ & $\begin{array}{l}\text { 09:00 } \\
\text { WIB }\end{array}$ & $\begin{array}{l}\text { Class survey and distributing } \\
\text { questionnaires (pre-test) } \\
\text { Experiment Group }\end{array}$ \\
\hline \multicolumn{4}{|c|}{ Experiment Group } \\
\hline 3 & Monday, 08 June 2020 & $\begin{array}{l}\text { 09:00 } \\
\text { WIB }\end{array}$ & $\begin{array}{l}\text { First Session } \\
\text { Filling in the respondent's } \\
\text { agreement sheet, and discussing } \\
\text { a little about Hypnotherapy and } \\
\text { Hypnotherapy implementation } \\
\text { to each student. }\end{array}$ \\
\hline 4 & $\begin{array}{l}\text { Tuesday, } \\
\text { 09 June } 2020\end{array}$ & $\begin{array}{l}\text { 09:00 } \\
\text { WIB }\end{array}$ & $\begin{array}{l}\text { Second Session } \\
\text { Filling in the respondent's } \\
\text { agreement sheet, and discussing } \\
\text { a little about Hypnotherapy after } \\
\text { the implementation of } \\
\text { Hypnotherapy to each student }\end{array}$ \\
\hline
\end{tabular}




\begin{tabular}{|c|c|c|l|}
\hline 5 & 10-30 June 2020 & - & $\begin{array}{l}\text { Third Session } \\
\text { Students are under the influence } \\
\text { of hypnotherapy. }\end{array}$ \\
\hline 6 & $\begin{array}{c}\text { Wednesday, } \\
\text { 01 July 2020 }\end{array}$ & $\begin{array}{c}09: 00 \\
\text { WIB }\end{array}$ & $\begin{array}{l}\text { Fourth Session } \\
\text { Providing Post-test Sheet }\end{array}$ \\
\hline
\end{tabular}

Based on the post-test results, there is a significant change from the experimental class, we can see this in the table. This means that hypnotherapy services can affect student learning motivation, namely increasing the learning motivation of 29 State Junior High School, Bandar Lampung. The Wilcoxon test result is one of the nonparametric statistical tests. This test is used when the data is not normally distributed. In principle, the sample is tested whether the sample has changed after being given therapy or not.

Table 2. of Pre-test Results, Post-test and Gain Score for Experiment Class Pre-test Post-test Gain Score

\begin{tabular}{|c|l|c|c|c|}
\hline No & Student Initials & Pre-test & Post-test & Gain Score \\
\hline 1 & MK & 90 & 134 & 44 \\
\hline 2 & MRF & 101 & 142 & 41 \\
\hline 3 & NAP & 90 & 121 & 31 \\
\hline 4 & ULS & 98 & 130 & 32 \\
\hline 5 & YAP & 102 & 138 & 36 \\
\hline \multicolumn{2}{|c|}{ Amount } & $\mathbf{4 8 1}$ & $\mathbf{6 6 5}$ & $\mathbf{1 8 4}$ \\
\hline \multicolumn{2}{|l|}{ Average with N 5 } & $\mathbf{9 6 , 2}$ & $\mathbf{1 3 3}$ & $\mathbf{3 6 , 8}$ \\
\hline
\end{tabular}

From the table above, it can be seen that there is a significant increase from before being given treatment and after being given hypnotherapy service treatment in the experimental class. The pre-test average in the experimental class was 96 (included in the low category) <the post-test average in the experimental class was 133 (included in the High category), it can be concluded that there was an increase in the experimental class before and after being given treatment. Hypothesis testing is done using the Wilcoxon test. The following are the results of the Wilcoxon test in the experimental group using SPSS Version.20.

Table 3. Wilcoxon Signed Ranks Test Experiment Class

\begin{tabular}{|ll|l|l|l|}
\hline & N & $\begin{array}{c}\text { Mean } \\
\text { Rank }\end{array}$ & $\begin{array}{c}\text { Sum } \\
\text { Ranks }\end{array}$ \\
\hline \multirow{4}{*}{ Posttes - Pretes } & Negative Ranks & $0^{\mathrm{a}}$ & .00 & .00 \\
& Positive Ranks & $5^{\mathrm{b}}$ & 3.00 & 15.00 \\
& Ties & $0^{\mathrm{c}}$ & & \\
& Total & 5 & & \\
\hline
\end{tabular}

explanation
a. posttest $<$ pretest
b. posttest > pretest
c. posttest $=$ pretest

Based on the ranks table above, it can be seen that the data from the Wilcoxon signed ranks test results in a change in value both before and after being given treatment. Positive ranks with $\mathrm{N}=5$ means that all samples have increased from pre-test to post-test. Meanwhile, the mean rank increased by 3.00 and the sum of ranks or the number of positive ranks was 
15.00 and the value of the ties was 0 . This means that there is no similarity between the pretest and post-test scores.

Table 3. Test Statistic

\begin{tabular}{|l|l|}
\hline & Posttest-pretest \\
\hline$Z$ & $-2.023-^{\mathrm{a}}$ \\
\hline Asymp. Sig. (2-tailed) & .043 \\
\hline
\end{tabular}

a. Wilcoxon Signed Ranks Test

b. Based on negativ ranks

In the statistical test table above, it can be seen that there is an increase from before and after being given treatment. The results obtained show that the calculated $\mathrm{Z}$ value obtained is -2.023 , while the $\mathrm{Z}$ table value obtained from the $\mathrm{Z}$ table with an alpha of 0.05 or the same value as 5\%. From these data it is also known that the Asymp.sig (2-tailed) value obtained is 0.043 . Because $\mathrm{Z}$ count $>\mathrm{Z}$ table that is $-2.023>-1.96$ or the sig value. 0.043 $<0.05$. Thus, according to the statistical test provisions used, Ho is rejected and $\mathrm{Ha}$ is accepted. This means that there is a difference between the results of the pre-test and posttest, so it can be concluded that hypnotherapy services are used to increase learning motivation in students at 29 State Junior High School, Bandar Lampung. Below is a curve that shows Ho is rejected and Ha is accepted.

Table 4. One-Sample Kolmogorov-Smirnov Test

\begin{tabular}{|ll|c|c|}
\hline & & Posttest & Pretest \\
\hline $\mathrm{N}$ & & 5 & 5 \\
Normal Parameters & & \\
& Mean & 96.20 & 133.00 \\
Most Extreme Differences & Std. Devitation & 5.848 & 8.062 \\
& Absolute & .255 & .155 \\
& Positive & .255 & .132 \\
& Negative & -.221 & -.155 \\
Kolmogorov-Smirnov Z & & .571 & .346 \\
Asymp. Sig. (2 tailed) & & .900 & 1.000 \\
\hline
\end{tabular}

From the table above, it can be seen that the mean pre-test result is 96.20. In the posttest results, the mean value obtained is 133.00 . Therefore, there was a significant increase before and after being given treatment in the form of hypnotherapy services to increase student motivation. It was revealed that the descriptive data in the analysis were as follows: Mean Pre-test: 96.20 (included in the low category) Mean Post-test: 133.00 (included in the high category).

Hypnotherapy is an alternative therapy to solve mental problems such as trauma in the past, anxiety, fear, and so on. Hypnotherapy brings the client who is being treated from the normal stage of consciousness to the stage of hypnosis. In the hypnosis stage, there is a decrease in brain waves from beta waves to alpha or theta waves. This decrease in waves makes the client feel more relaxed and suggestive in accepting new suggestions. Because hypnotherapy makes students' minds relax, so learning becomes fun, making memorization easier.

This is supported by research that says hypnotherapy opens access to the subconscious mind which stores various kinds of memories (Garba \& Mamman, 2020). When this access is opened, something that has been forgotten can easily be remembered 
again. Including memory when I was under 3 years old. Often it happens to children, when they face learning, forget what they have learned. But after being outside the classroom I remember everything. it is because the mind is tense as if all memories are closed so that they forget (Zeig \& Tanev, 2020). Supported by research that finds hypnotherapy as therapeutic importance, which can overcome learning stress, increase motivation, can improve one's bad habits and can also strengthen memory (BoVee-Akyurek et al., 2020). With the hypnotherapy method, the role of students will be helped so that it will facilitate the learning process. Reading will be much faster and when memorizing will be much easier, because all access to the mind and brain will be directed there (Shakil, 2020). Based on the research, it can be concluded that hypnotherapy affects the learning motivation of students 29 State Junior High School, Bandar Lampung. This is reinforced by the results of the post-test, as well as interviews with students who have low learning motivation. The counselee stated that he felt more enthusiastic about doing positive things, especially studying. meaning he has improved. Students who were lazy to study are now more enthusiastic and more focused. This means that hypnotherapy affects learning motivation in students of 29 State Junior High School, Bandar Lampung. Hypnotherapy can arouse students' enthusiasm in learning and can suggest various positive things that aim to increase self-confidence, motivation, and a positive selfimage.

\section{Conclusions and Suggestions}

Based on the results of the study, it can be concluded that hypnotherapy services have an effect on student motivation at 29 State junior High School, Bandar Lampung. In the hypnosis stage there is a decrease in brain waves from beta waves to alpha or theta waves. This decrease in waves makes the client feel more relaxed and suggestive in accepting new suggestions. So that learning motivation can increase, for further researchers it is recommended to carry out controlled services, so that the results obtained can be maximized.

\section{References}

Alizamar, A., Ifdil, I., Fadli, R. P., Erwinda, L., Zola, N., Churnia, E., Bariyyah, K., Refnadi, R., \& Rangka, I. B. (2018). The effectiveness of hypnotherapy in reducing stress levels. Addictive Disorders \& Their Treatment, 17(4), 191-195.

Becirovic, S. (2017). The Relationship between Gender, Motivation and Achievement in Learning English as a Foreign Language. European Journal of Contemporary Education, 6(2), 210-220.

BoVee-Akyurek, A., Erolin, K., \& Chenail, R. (2020). Ericksonian Hypnotherapy Resemblances in Solution Focused Brief Therapy. Contemporary Family Therapy, 42(4), 408-421.

Denzinger, F., \& Brandstätter, V. (2018). Stability of and changes in implicit motives. A narrative review of empirical studies. Frontiers in Psychology, 9, 777.

Garba, M. H., \& Mamman, M. (2020). Hypnosis and Hypnotherapy: The Role of Traditional Versus Alternative Approach. Hypnotherapy and Hypnosis.

Imelda, I., Faeni, D. P., Faeni, R. P., Meidiyustiani, R., \& Oktaviani, R. F. (2019). "WAZZ Up Doc?" Cost Efficient, User Friendly, Patient Trust Level Based on Convenience and the Use of Hypnotherapy Mobile Apps Method. International Journal of Business Studies, 3(3), 104-109.

Khayatjadidi, H., Younesi, S. J., \& Izadi, M. (2021). The Effect of Education Using 
Cognitive-Behavioral Hypnotherapy $(\mathrm{CBH})$ on Self-Esteem of Students with High Induction. Journal of Nursing Education, 9(6), 49-59.

Lin, M.-H., \& Chen, H. (2017). A study of the effects of digital learning on learning motivation and learning outcome. Eurasia Journal of Mathematics, Science and Technology Education, 13(7), 3553-3564.

Locke, E. A., \& Schattke, K. (2019). Intrinsic and extrinsic motivation: Time for expansion and clarification. Motivation Science, 5(4), 277.

Puspitasari, W. D. (2018). Implementasi Metode Hypnoteaching untuk Meningkatkan Hasil Belajar Siswa Sekolah Dasar. Jurnal Cakrawala Pendas, 4(1).

Ryan, R. M., Bradshaw, E., \& Deci, E. L. (2019). A history of human motivation theories. In The Cambridge handbook of the intellectual history of psychology. Cambridge University Press Cambridge, UK.

Shakil, M. (2020). Integration of hypnotherapy with brief cognitive behaviour therapy (CBT) for treatment of depression. JPMA. The Journal of the Pakistan Medical Association, 70(4), 719-723.

Taufik, A., \& Upoyo, A. S. (2019). Hypnotherapy Improve Motivation And Learning Outcomes Students In The Block System Learning Method. Journal of Bionursing, 1(2), $153-162$.

Zeig, J. K., \& Tanev, K. S. (2020). Marital Hypnotherapy: A Session with Milton Erickson with Commentary. International Journal of Clinical and Experimental Hypnosis, 68(3), 263-288. 
